\title{
115 year ice-core data from Akademii Nauk ice cap, Severnaya Zemlya: high-resolution record of Eurasian Arctic climate change
}

\author{
Thomas OPEL, ${ }^{1,2}$ Diedrich FRITZSCHE, ${ }^{1}$ Hanno MEYER, ${ }^{1}$ Rainer SCHÜTT, ${ }^{1}$ \\ Karin WEILER, ${ }^{3,4}$ Urs RUTH, ${ }^{3}$ Frank WILHELMS, ${ }^{3}$ Hubertus FISCHER ${ }^{3,4}$ \\ ${ }^{1}$ Alfred Wegener Institute for Polar and Marine Research, PO Box 600149, D-14401 Potsdam, Germany \\ E-mail: thomas.opel@awi.de \\ ${ }^{2}$ Department of Geography, Humboldt-Universität zu Berlin, Unter den Linden 6, D-10099 Berlin, Germany \\ ${ }^{3}$ Alfred Wegener Institute for Polar and Marine Research, PO Box 120161, D-27515 Bremerhaven, Germany \\ ${ }^{4}$ Climate and Environmental Physics, Physics Institute, University of Bern, Sidlerstrasse 5, CH-3012 Bern, Switzerland
}

\begin{abstract}
From 1999 to 2001 a 724 m deep ice core was drilled on Akademii Nauk ice cap, Severnaya Zemlya, to gain high-resolution proxy data from the central Russian Arctic. Despite strong summertime meltwater percolation, this ice core provides valuable information on the regional climate and environmental history. We present data of stable water isotopes, melt-layer content and major ions from the uppermost $57 \mathrm{~m}$ of this core, covering the period 1883-1998. Dating was achieved by counting seasonal isotopic cycles and using reference horizons. Multi-annual $\delta^{18} \mathrm{O}$ values reflect Eurasian subArctic and Arctic surface air-temperature variations. We found strong correlations to instrumental temperature data from some stations (e.g. $r=0.62$ for Vardø, northern Norway). The $\delta^{18} \mathrm{O}$ values show pronounced 20th-century temperature changes, with a strong rise about 1920 and the absolute temperature maximum in the 1930s. A recent decrease in the deuterium-excess time series indicates an increasing role of the Kara Sea as a regional moisture source. From the multi-annual ion variations we deduced decreasing sea-salt aerosol trends in the 20th century, as reflected by sodium and chloride, whereas sulphate and nitrate are strongly affected by anthropogenic pollution.
\end{abstract}

\section{INTRODUCTION}

Ice cores are well known as one of the best archives for providing information on palaeoclimatic and palaeoenvironmental changes. These data are very valuable for climate research, especially for regions or time periods with only few meteorological observations. For the Arctic, ice cores from the dry snow zone of the Greenland ice sheet contribute data of more than 100000 years (e.g. North Greenland Ice Core Project (NorthGRIP) members, 2004). However, for a more comprehensive view on the climate changes on a more regional scale and over shorter timescales, more data from Arctic regions outside Greenland are needed. Therefore, in the Eurasian Arctic several ice cores from ice caps on Svalbard (Isaksson and others, 2001; Watanabe and others, 2001) and on Franz Josef Land (FJL) (Henderson, 2002) have been drilled and analysed recently. Ice caps in the Eurasian Arctic are relatively small and have a relatively low altitude compared with the Greenland ice sheet as well as with Canadian Arctic ice caps. Moreover, they have higher accumulation rates. Thus, they mostly contain records of only several hundred years. Additionally, they are characterized by summer surface melting and infiltration processes, which alter these ice-core records further (e.g. Koerner, 1997). Nevertheless, the small Arctic ice caps contain valuable palaeoclimatic and palaeoenvironmental records (e.g. Henderson, 2002; Isaksson and others, 2005).

The easternmost considerable ice caps of the Arctic exist on the Severnaya Zemlya (SZ) archipelago, located in the central Russian Arctic between the Kara Sea in the west and the Laptev Sea in the east (Fig. 1). SZ is vulnerable to climatic and environmental changes due to its position in the high latitudes and in the transition zone from the Atlantic-influenced western Siberian to continental eastern
Siberian Arctic climate. In the last few decades, several ice cores have been drilled on SZ ice caps (see section 2). They were analysed only at a relatively low resolution, resulting in an uncertain maximum time resolution and questionable timescales. To improve the resolution of palaeoclimatic data, to check the previous timescales and to evaluate the alteration of the original atmospheric deposition by melting and infiltration, a new $724 \mathrm{~m}$ long surface-to-bedrock core was drilled on Akademii Nauk (AN) ice cap from 1999 to 2001 at $80^{\circ} 31^{\prime} \mathrm{N}, 94^{\circ} 49^{\prime} \mathrm{E}$ (Fritzsche and others, 2002).

In this paper, we present high-resolution data of stable water isotopes, melt-layer content as well as major ions from the uppermost $57 \mathrm{~m}$ of this core, covering the time period 1883-1998. The uppermost $57 \mathrm{~m}$ section was chosen because this is the only section with high-resolution ion data. We discuss the palaeoclimatic significance of the icecore proxies by comparing them with meteorological and palaeoclimatic data from the Eurasian sub-Arctic and Arctic and the deduced climatic features.

\section{PREVIOUS SEVERNAYA ZEMLYA ICE CORES}

Between 1978 and 1988, scientists from the former Soviet Union drilled eight ice cores on SZ (seven on Vavilov ice cap and one on AN ice cap) (Kotlyakov and others, 2004). Six of these cores were sampled and analysed, but only at low resolution (about $2 \mathrm{~m}$ and less). Some of these data are available, provided by the database 'Deep Drilling of Glaciers in Eurasian Arctic' (DDGA) at http://www. pangaea.de/search?q=ddga.

Dating of these cores was achieved by a combination of annual-layer counting (based on variations of optical density, electrical conductivity and non-specified stratigraphic 


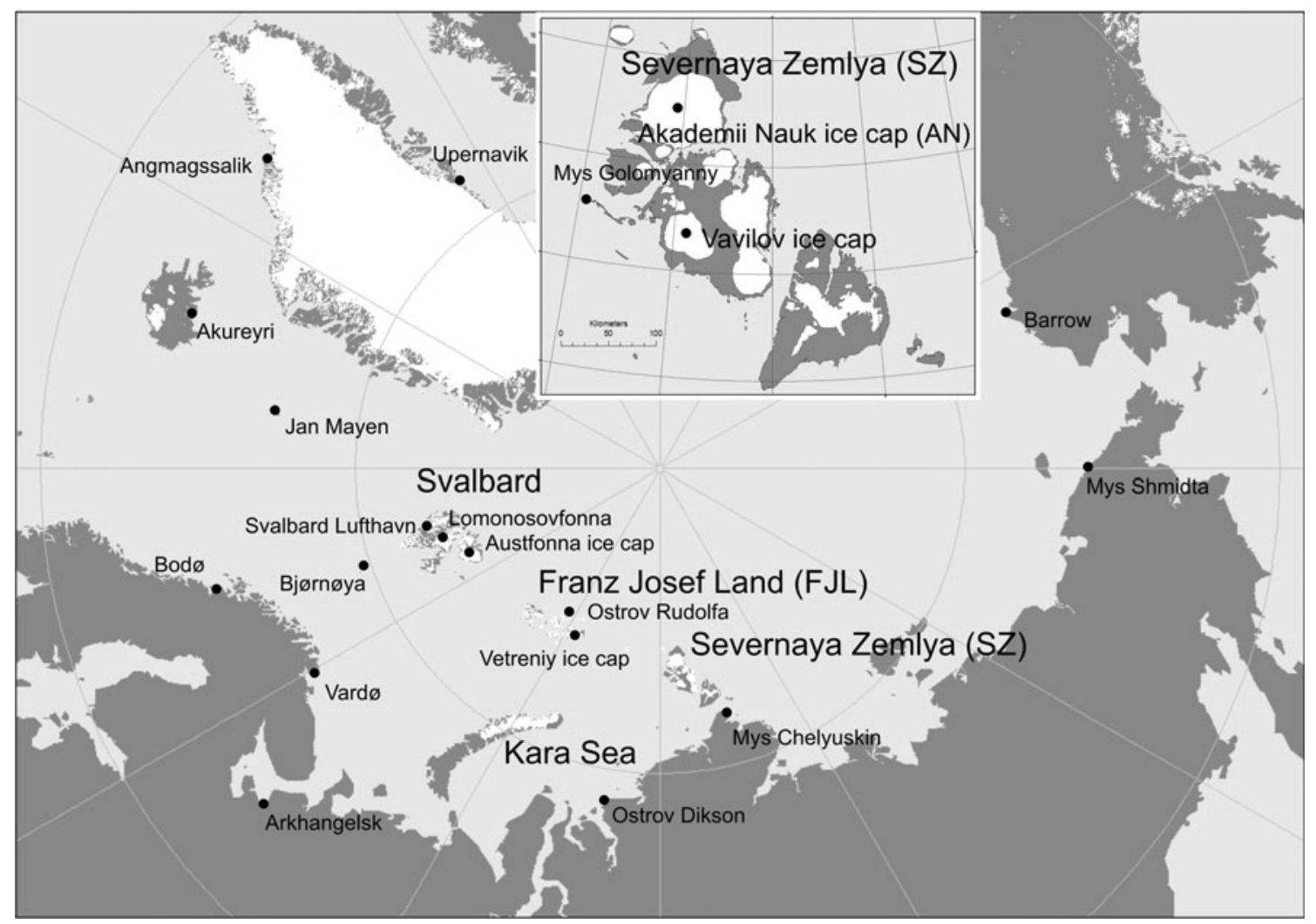

Fig. 1. Map of the Arctic. Inset shows a detailed map of Severnaya Zemlya (SZ) archipelago. All locations referred to in the text are labelled.

features), ice-flow modelling and wiggle matching with icecore records from Greenland and Antarctica. These methods led to different age models for the SZ ice cores. For the near-bottom ice layers of AN ice cap as well as of Vavilov ice cap, ages between 10 and $40 \mathrm{kyr}$ were published, but due to uncertainties in the applied dating methods, these ages seem to be distinctly overestimated (Kotlyakov and others, 2004, and references therein). However, according to Koerner and Fisher (2002), AN ice cap, as the thickest and coldest ice cap on SZ, is the only one in the Eurasian Arctic with the potential for a Late Pleistocene age.

Stable-isotope data $\left(\delta^{18} \mathrm{O}, \delta \mathrm{D}\right)$ from the previous ice cores revealed a marked warming trend for the last 150 years (Tarussov, 1992; Kotlyakov and others, 2004). The older climatic implications, though, are questionable due to the aforementioned inadequate dating methods.

\section{STUDY AREA}

\subsection{Climate conditions on Severnaya Zemlya}

In general, the climate of SZ is typical for the High Arctic. The large-scale atmospheric circulation is dominated by the low-pressure area over the Barents Sea and Kara Sea and by the high-pressure areas over Siberia and the Arctic Ocean (Bolshiyanov and Makeev, 1995; Alexandrov and others, 2000). During wintertime, anticyclone circulation connected with the Siberian and Arctic highs dominates, but cyclones coming from the Kara Sea reach the archipelago. In spring, the circulation shows winter characteristics, but with lower pressure gradients and cyclone activity. The summer is characterized by continually decreasing cyclone activity and the formation of a high-pressure area. In autumn, wintertime pressure fields start to develop and the cyclone activity increases to its annual maximum.

Meteorological measurements on SZ started only in 1930. Unfortunately, there are some data gaps in the 1930s and 1940s. Golomyanny station (Fig. 1; World Meteorological Organization (WMO) number 20087), located on a small island at the western tip of SZ (7 ma.s.l.), has an annual mean surface air temperature (SAT) of $-14.7^{\circ} \mathrm{C}$ for the period 1951-80 (Alexandrov and others, 2000). After a SAT maximum in the 1950s, Golomyanny data show a cooler period until 1980 and a warming trend since 1990, though without reaching the values of the 1950s (data from Polyakov and others, 2003b, http://www.frontier.iarc.uaf. edu/ igor/research/data/airtemppres.php).

Annual mean precipitation is $186 \mathrm{~mm}$ at Golomyanny station (Alexandrov and others, 2000), whereas the ice caps receive about $400 \mathrm{~mm}$ distributed throughout the year, with maxima in summer and autumn (Bolshiyanov and Makeev, 1995). According to the general circulation pattern, Bolshiyanov and Makeev (1995) demonstrated that the main part of precipitation on Vavilov ice cap occurs in connection with southerly and southwesterly winds, caused by northeastward movement of moisture-bearing cyclones over the Kara Sea. The autumn precipitation maximum is connected to the increase in cyclonic activity: depressions causing much precipitation move from the North Atlantic. Cyclones, formed over northern Europe and western Siberia, are responsible for the summer precipitation maximum. An air-mass transport mainly from Asia, northern Eurasia, Europe and the Atlantic Ocean, as identified by trajectory analysis for spring (Vinogradova and Egorov, 1996) and summer (Vinogradova and Ponomareva, 1999), confirms 
these findings. We assume a similar pattern and origin of precipitation for the nearby $\mathrm{AN}$ ice cap, situated about $150 \mathrm{~km}$ north of Vavilov ice cap.

\subsection{Drilling-site characterization and melting processes}

Covering an area of $5575 \mathrm{~km}^{2}$, the dome-shaped AN ice cap is the largest in the whole Russian Arctic, reaching a maximum elevation of about $750 \mathrm{~m}$ a.s.l. (Dowdeswell and others, 2002). To avoid a disturbed core stratigraphy, the drilling site was chosen in an area with flat subglacial topography and low horizontal ice-flow velocity (Fritzsche and others, 2002). Although situated near the summit, the drilling site is located in the percolation zone and therefore, like almost all Arctic ice caps outside interior Greenland, is affected by infiltration of meltwater during summer. We assume that melting and infiltration processes occur in almost every summer due to temperatures above $0^{\circ} \mathrm{C}$ and/or high insolation.

An automatic weather station (AWS) was run at the drilling site between May 1999 and May 2000, with a data gap of 2 months (during February and April 2000) due to a breakdown in power supply (Kuhn, 2000). The AWS data give the opportunity to characterize the temperature conditions near the drilling point for the 1999 summer season. Figure 2 illustrates daily mean values of air temperature $(2.5 \mathrm{~m}$ above snow cover at the start in May 1999), snow height (calculated from the distance between sensor and snow cover, relative to the start) and snow temperature $(0.5 \mathrm{~m}$ below snow cover at the start). Clearly visible are temperatures above $0^{\circ} \mathrm{C}$ in July and August, causing snowmelt and decrease of snow height. Strong increases in snow temperature within a few days, corresponding with decreasing snow height, indicate infiltration events. The meltwater pulses connected with latent-heat flow reach depths of $1 \mathrm{~m}$ (height difference between snow height and snow temperature logger) as a minimum, at least in fresh snow. At the end of August, almost all the snow that had fallen since May had sintered and melted, before new snow accumulation began. The maximum percolation depth on AN ice cap is uncertain. However, percolation deeper than two to three annual layers seems unlikely, since the ice layers, formed by refrozen meltwater, should be barriers to further infiltration. For the Lomonosovfonna ice core, extensive study by Pohjola and others (2002a) showed that the infiltrated meltwater typically refreezes within the recent annual layer.

The annual mean air temperature for May 1999-April 2000 was calculated as $-15.7^{\circ} \mathrm{C}$ (Kuhn, 2000). Compared with the measured $10 \mathrm{~m}$ depth temperature of $-10.2^{\circ} \mathrm{C}$ in April 2000, this indicates latent-heat flow of infiltrating meltwater, as mentioned above. From a comparison of AWS and Golomyanny SAT data, we calculated a mean temperature gradient of $-0.5^{\circ} \mathrm{C}$ per $100 \mathrm{~m}$ altitude, with lowest values in summer and highest values in autumn as a result of sea-level freezing processes with release of latent heat.

\section{METHODS}

The AN ice core was processed and sampled in the cold laboratory of the Alfred Wegener Institute for Polar and Marine Research in Bremerhaven. At first, electrical conductivity and density were determined in $5 \mathrm{~mm}$ resolution by using dielectrical profiling and $\gamma$-absorption techniques

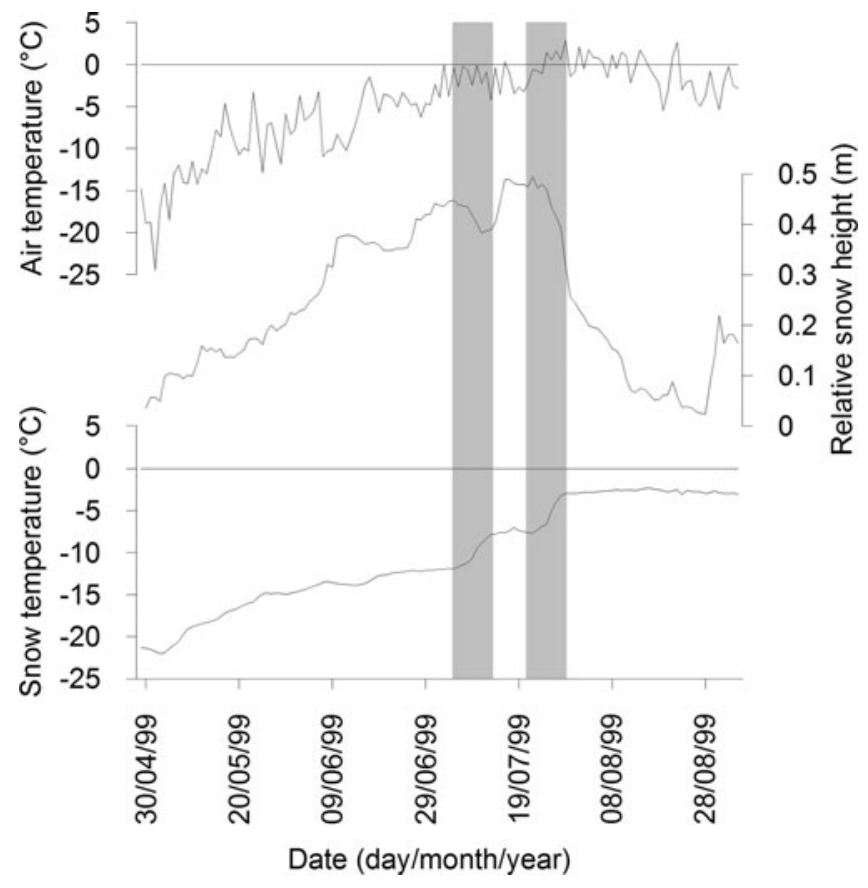

Fig. 2. Data from an AWS near the drilling site for time period MayAugust 1999: air temperature $(2.5 \mathrm{~m}$ above snow cover at the start in May 1999), relative snow height (relative to start in May 1999) and snow temperature $(0.5 \mathrm{~m}$ below snow cover at start in May 1999). The horizontal black lines indicate $0^{\circ} \mathrm{C}$. Grey shaded areas indicate infiltration events with decreasing snow height and increasing snow temperature.

(Wilhelms, 2000). Thereafter, two core-axis-parallel slices were cut. Samples for stable water-isotope measurements were taken from the first $11 \mathrm{~mm}$ thick slice at a very high resolution of $25 \mathrm{~mm}$. To determine $\delta^{18} \mathrm{O}$ and $\delta \mathrm{D}$ we used a Finnigan-MAT Delta $S$ mass spectrometer with an analytical precision of better than $\pm 0.1 \%$ for $\delta^{18} \mathrm{O}$ and $\pm 0.8 \%$ for $\delta \mathrm{D}$ (Meyer and others, 2000). In total, we analysed 2248 samples for the $57 \mathrm{~m}$ considered here.

The second $30 \mathrm{~mm}$ thick slice was polished and scanned with a line-scan camera (Svensson and others, 2005) for stratigraphical analysis and identification of melt layers. Subsequently, these slices were used for glaciochemical studies. For the uppermost $53 \mathrm{~m}$, discrete samples were taken continuously under clean conditions at a resolution of $60 \mathrm{~mm}$ (for details of sampling see Weiler and others, 2005). For the remaining $4 \mathrm{~m}$ of the considered core section, we took discrete samples at a resolution of about $30 \mathrm{~mm}$ by using a melting device for continuous flow analysis (CFA) coupled with an autosampler system, which was also used for the analysis of the ice cores from Greenland (NorthGRIP) and Antarctica (European Project for Ice Coring in Antarctica (EPICA)) (for details see Ruth and others, 2004). A Dionex IC20 ion chromatograph was used to analyse the melted samples for anions (methanesulphonate ( $\left.\mathrm{MSA}^{-}\right), \mathrm{Cl}^{-}, \mathrm{NO}_{3}{ }^{-}$, $\mathrm{SO}_{4}{ }^{2-}$ ) and cations $\left(\mathrm{Na}^{+}, \mathrm{NH}_{4}{ }^{+}, \mathrm{Mg}^{2+}, \mathrm{Ca}^{2+}\right.$ ) (for details see Weiler and others, 2005).

\section{DATING APPROACH AND AGE MODEL}

We dated the presented ice-core section and determined the annual layer thickness by identifying different reference horizons as well as by counting seasonal isotopic cycles. As reference horizon, we used the 1963 radioactivity peak 

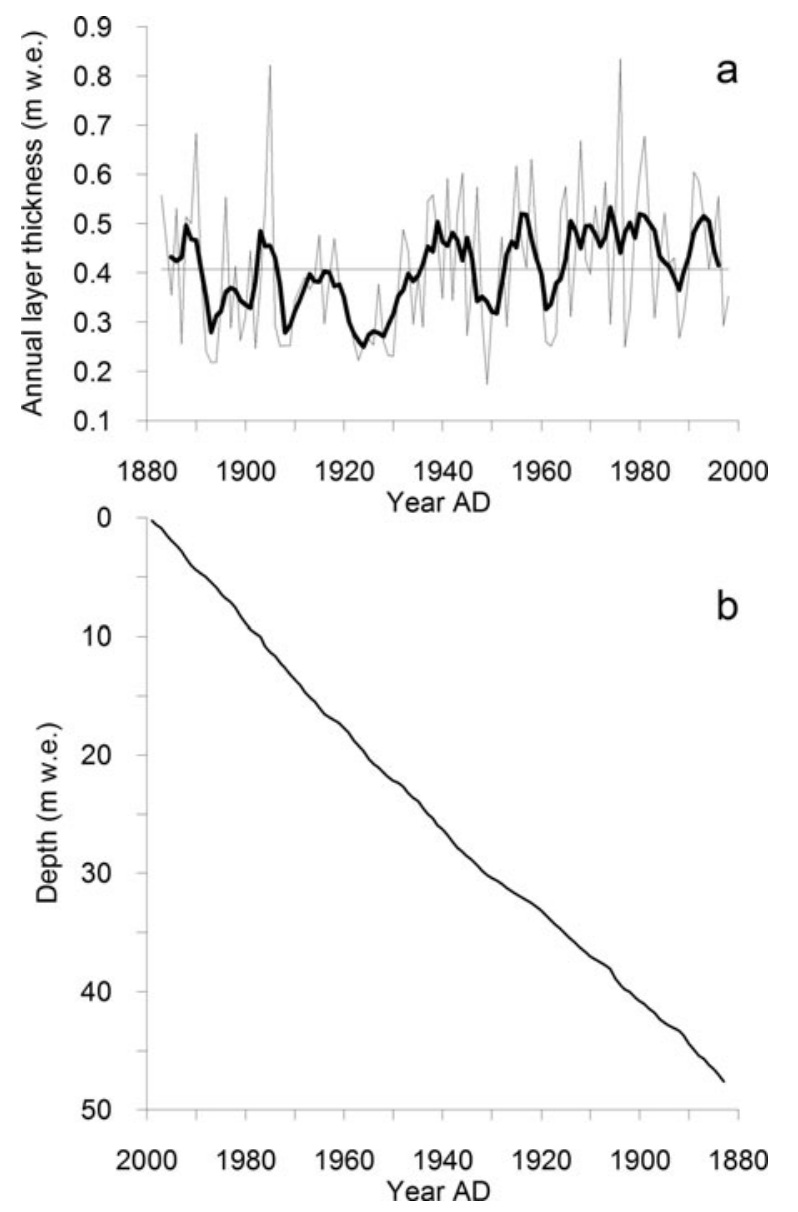

Fig. 3. (a) Thickness of the thinned (not decompressed) annual layers (grey line: annual values; thick black line: 5 year running mean (5yrm) values; horizontal line: long-term mean) and (b) depth-age relationship as result of the age model.

caused by the fallout from nuclear bomb tests, as determined by ${ }^{137} \mathrm{Cs}$ measurements (Fritzsche and others, 2002; Pinglot and others, 2003). Additionally, we interpreted two peaks in electrical conductivity as well as sulphate as deposits of the volcanic eruptions of Bezymianny, Kamchatka, in 1956 (Weiler and others, 2005) and of Katmai, Alaska, in 1912 (section 6.3).

Seasonal signals of $\delta^{18} \mathrm{O}, \delta \mathrm{D}$ and deuterium excess $\mathrm{d}$ $\left(\mathrm{d}=\delta \mathrm{D}-8 \delta^{18} \mathrm{O}\right)$ are detectable in AN ice-core isotopic data, even though altered from the originally deposited signal in the snowpack and smoothed due to melting and infiltration processes. The counted annual marks $\left(\delta^{18} \mathrm{O}\right.$ winter minima and corresponding $d$ maxima) confirm the reference horizons and yield an age of 116 years at annual resolution for the $57 \mathrm{~m}$ core section studied. As a result of the high-resolution sampling, each year is represented by a mean of 20 samples (min. 9, max. 44). However, the possibility of substantial runoff or strong modification of the original isotopic signature has to be taken into account. This could lead to complete smoothing of annual cycles or creation of additional peaks, which could possibly be counted as additional years.

The resulting depth-age relationship and annual layer thickness are displayed in Figure 3. The annual layer thickness shows distinct variations on different scales. The mean value for the period $1883-1998$ is $0.41 \mathrm{mw}$.e. In general, the mean annual layer thickness shows lower values
(0.36 mw.e.) before and higher values $(0.44 \mathrm{mw}$.e.) after 1935. A similar increase of annual layer thickness in the second half of the 20th century also occurred on Lomonossovfonna, Svalbard (Pohjola and others, 2002b).

As another approach for dating the upper AN ice-core section, Weiler and others (2005) counted $\mathrm{Na}^{+}$peaks as assumed annual markers. They determined 94 years in the 0-53 $\mathrm{m}$ core section, 15 years less than by the abovementioned dating method for the same depth interval. Deviations between the two dating approaches occur over the whole core section, but mainly in the 1950s and 1920s, probably caused by strong melting.

Evidence for the reliability of our age model is given by the coincidence of a strong rise at about 1920 in both the $\delta^{18} \mathrm{O}$ and SAT data (as shown in Fig. 5 below), which could be used as additional reference horizon (Watanabe and others, 2001). This leads to the conclusion that the chemical profile of the AN ice core is modified more by infiltration processes than the isotopic record, as reported also for a Svalbard ice core from Lomonosovfonna (Pohjola and others, 2002a). Therefore, counting seasonal isotopic cycles and cross-checking with reference layers seem to be more promising for dating the $\mathrm{AN}$ ice core than counting chemical signals. In the following discussion, we use the dating shown in Figure 3 and estimate the dating accuracy to be better than \pm 3 years after 1920 and up to \pm 5 years at the end of the 19th century.

Fritzsche and others (2005) found that AN ice cap was not in dynamic steady state, but had been growing until recent times. They calculated the age of the near-bottom ice of the AN ice core at approximately 2500 years. Therefore, it is distinctly younger than assumed before drilling this ice core. Most likely, the AN ice cap had disappeared almost completely during the Holocene thermal maximum and started growing again to the present state thereafter.

\section{RESULTS, CLIMATIC IMPLICATIONS AND DISCUSSION}

\subsection{Stable water-isotope ratios $\delta^{18} \mathrm{O}$ and $\delta \mathrm{D}$}

Due to their dependence on condensation temperatures, stable water-isotope ratios $\delta^{18} \mathrm{O}$ and $\delta \mathrm{D}$ in precipitation are commonly accepted as valuable proxy for local- to regionalscale temperatures in high polar latitudes. For the AN ice core, the relationship between all $\delta^{18} \mathrm{O}$ and $\delta \mathrm{D}$ values in the presented core section is $\delta \mathrm{D}=7.46 \delta^{18} \mathrm{O}-0.11\left(R^{2}=0.98\right.$, $n=2248$; Fig. 4). Considering only the annual mean values, derived by averaging all isotope values between the defined annual marks, the isotopic relationship is calculated as $\delta \mathrm{D}=7.55 \delta^{18} \mathrm{O}+1.84\left(R^{2}=0.99, n=116\right.$; Fig. 4). Both relationships are close together and can be interpreted as a local meteoric waterline (LMWL). Additionally, they differ only slightly from the global meteoric waterline (GMWL), which is defined theoretically as $\delta \mathrm{D}=8 \delta^{18} \mathrm{O}+10$ (Craig, 1961) and calculated on a global scale as $\delta \mathrm{D}=8.17 \delta^{18} \mathrm{O}+10.35$ (Rozanski and others, 1993). From this, it follows that the mean isotopic composition of the AN ice core is not affected by considerable changes owing to evaporation. Therefore, the AN ice-core stable-isotope data seem to be suitable for palaeoclimate studies. Statistical descriptions of the stable water-isotope data (single values and annual mean values) are given in Table 1.

For palaeoclimatic consideration of stable-isotope data, we focused on $\delta^{18} \mathrm{O}$, which is more common in Arctic ice- 

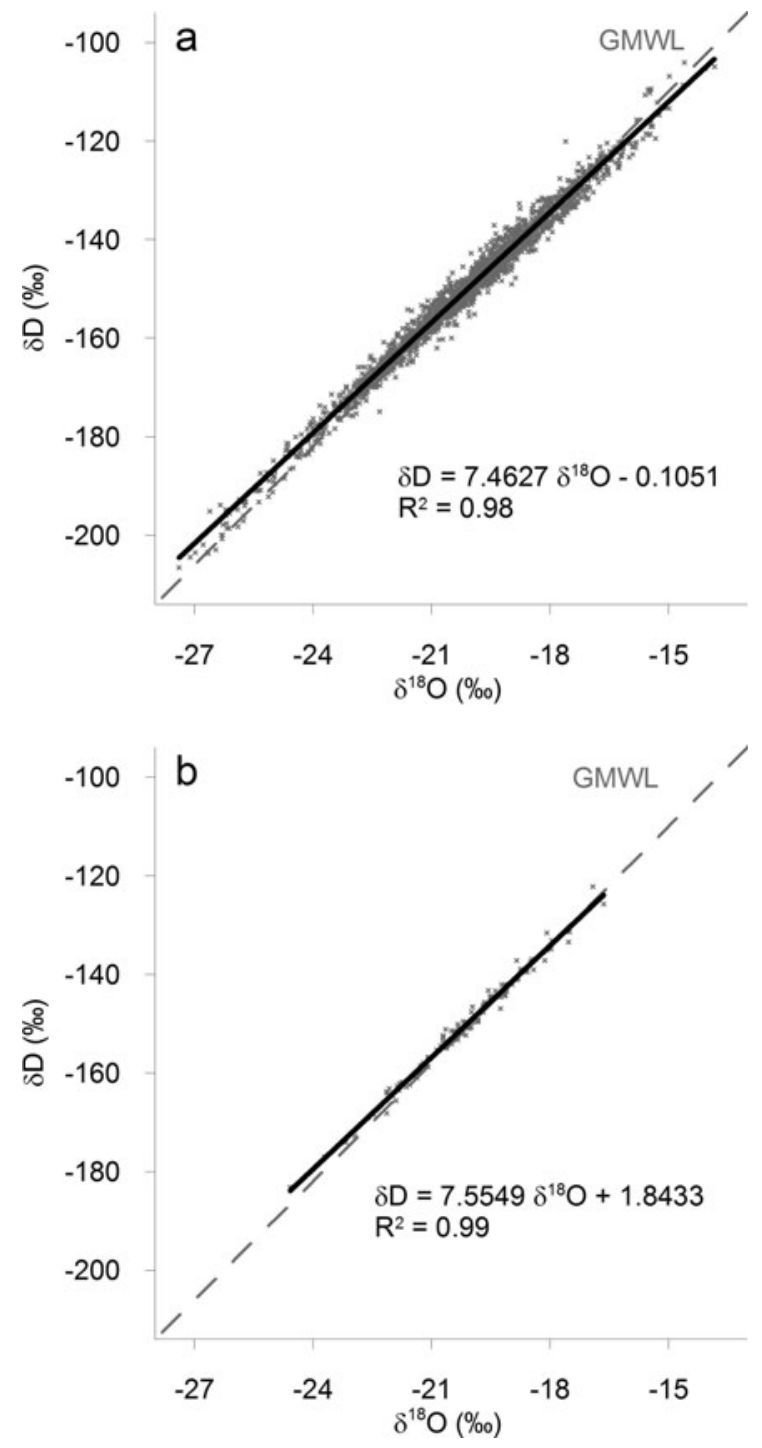

Fig. 4. $\delta^{18} \mathrm{O}-\delta \mathrm{D}$ diagram for single values (a) and annual values (b) of the AN ice core. Grey dots represent single values, the thick black lines represent the regression fit and the dashed grey line represents the GMWL.

core studies and therefore suitable for comparisons. To evaluate the palaeoclimatic significance of $\mathrm{AN} \delta^{18} \mathrm{O}$ data, we compared them with instrumental as well as composited SAT time series and other ice-core data. For the calculation of correlation coefficients the time series were detrended by removing the linear trends. We used annual mean values and 5 year running mean (5yrm) values of $A N \delta^{18} \mathrm{O}$ and SAT data, since the effects of melting, infiltration and refreezing processes on the stable-isotope data should be reduced or even negligible when smoothing the dataset over 5 years.

We did not find any good agreement between AN $\delta^{18} \mathrm{O}$ data and SAT time series from the nearest meteorological station, Golomyanny $\left(r_{5 y \mathrm{rm}}=0.27\right.$; data from Polyakov and others, 2003b). Since Golomyanny is situated on a small island only $7 \mathrm{~m}$ a.s.l., we assume that its SAT is controlled mainly by the local occurrence of sea ice, especially in the summer and autumn seasons. It therefore represents a very local climate. In contrast, temperature conditions at the AN ice-cap summit, as well as at the precipitation condensation level, are relatively independent of the local sea-ice occurrence at Golomyanny.
Table 1. Statistical descriptions of AN ice-core stable water-isotope data

\begin{tabular}{|c|c|c|c|c|c|c|}
\hline & \multicolumn{2}{|c|}{$\delta^{18} \mathrm{O}$} & \multicolumn{2}{|c|}{$\delta \mathrm{D}$} & \multicolumn{2}{|c|}{ d } \\
\hline & $\begin{array}{l}\text { Single } \\
\text { values }\end{array}$ & $\begin{array}{c}\text { Annual } \\
\text { mean } \\
\text { values }\end{array}$ & $\begin{array}{l}\text { Single } \\
\text { values }\end{array}$ & $\begin{array}{c}\text { Annual } \\
\text { mean } \\
\text { values }\end{array}$ & $\begin{array}{l}\text { Single } \\
\text { values }\end{array}$ & $\begin{array}{c}\text { Annual } \\
\text { mean } \\
\text { values }\end{array}$ \\
\hline$n$ & 2248 & 116 & 2248 & 116 & 2248 & 116 \\
\hline Max. (\%o) & -13.8 & -16.6 & -104.0 & -122.2 & 20.8 & 14.0 \\
\hline Min. (\%o) & -27.4 & -24.6 & -206.5 & -183.1 & 2.7 & 6.8 \\
\hline Range (\%o) & 13.6 & 7.9 & 102.5 & 60.9 & 18.1 & 7.2 \\
\hline Mean (\%o) & -20.1 & -20.2 & -150.0 & -150.7 & 10.7 & 10.8 \\
\hline Median (\%o) & -20.0 & -20.2 & -149.1 & -150.8 & 10.7 & 10.9 \\
\hline Variance $(\%)$ & 4.0 & 2.0 & 225.8 & 114.6 & 4.9 & 2.1 \\
\hline Std dev. (\%) & 2.0 & 1.4 & 15.0 & 10.7 & 2.2 & 1.4 \\
\hline
\end{tabular}

Since there are no Central Russian Arctic SAT time series reaching back to the 19th century, we chose additional stations, mainly from the Atlantic and Eurasian sub-Arctic, with respect to their spatial vicinity on the one hand and temporal extension of the time series on the other. We present the correlations for some of these SAT time series in Table 2. The best accordance between $A N \delta^{18} \mathrm{O}$ and instrumental SAT time series (1883-1998) was found for Vardø $\left(r_{5 y \mathrm{rm}}=0.62\right)$ and Arkhangelsk $\left(r_{5 y \mathrm{rm}}=0.61\right)$ stations, located at the Barents Sea and White Sea coasts, respectively (Fig. 5; data from Climatic Research Unit (CRU), Norwich, UK; Brohan and others, 2006). Compared with Golomyanny, their SATs are not (or in the case of Arkhangelsk to a much lesser extent) influenced by the occurrence of sea ice. The good correlations and similarities of the time series reveal again the influence of the Atlantic Ocean via the Barents Sea and Kara Sea on SZ region SAT conditions. Additionally, we found a strong correlation $\left(r_{5 \mathrm{yrm}}=0.72\right.$; Fig. 5) with the composite Arctic (north of $\left.62^{\circ} \mathrm{N}\right)$ SAT anomalies time series of Polyakov and others (2003b). However, one should note that these strong correlations are mainly due to common multi-annual variability (Table 2 ).

The strong correlations to instrumental and composite SAT data show that AN $\delta^{18} \mathrm{O}$ data are representative for SAT changes, not only for the central Russian Arctic, but also for the western and possibly whole Eurasian Arctic and subArctic. Since there are no meteorological data from the central Russian Arctic and only a few time series in the Eurasian Arctic spanning more than 100 years, our highresolution $\mathrm{AN} \delta^{18} \mathrm{O}$ data are very valuable for further palaeoclimatic studies in the Eurasian Arctic.

The AN $\delta^{18} \mathrm{O}$ time series shows a distinct increasing trend with pronounced changes since 1883. Starting from a low level of about $-22 \%, \delta^{18} \mathrm{O}$ values increased to values of $-18 \%$ at about 1920 and 1940 . From 1950 to the 1980 s they oscillated about $-20 \%$ and rose again afterwards. Besides the strong warming in the first two decades of the 20th century the most prominent feature of the $\mathrm{AN} \delta^{18} \mathrm{O}$ time series is the double-peaked SAT maximum between 1920 and 1940. These values were not reached again until the end of our record in the 1990s. This agrees with the instrumental sub-Arctic and Arctic SAT data (Fig. 5). The double-peak structure of this SAT maximum seems to be a specific feature of the Eurasian Arctic, since the 1920 peak is not visible in 
Table 2. Correlation coefficients between the detrended time series of AN $\delta^{18} \mathrm{O}$ and of selected sub-Arctic and Arctic SAT ( $r_{\mathrm{y}}$ for annual mean values, $r_{5 y r m}$ for 5 year running mean values) in the given time periods. The reduced degrees of freedom due to autocorrelation were taken into account for the calculation of the levels of significance. The WMO stations are sorted from east to west (see Fig. 1)

\begin{tabular}{|c|c|c|c|c|}
\hline WMO station & WMO number & Period & $r_{y}$ & $r_{5 y \mathrm{rm}}$ \\
\hline Mys Shmidta ${ }^{1}$ & 25173 & 1933-98 & $0.20^{+}$ & $0.66^{+++}$ \\
\hline Mys Chelyuskin ${ }^{1}$ & 20292 & 1933-98 & $0.21^{+}$ & 0.40 \\
\hline Mys Golomyanny ${ }^{1}$ & 20087 & $1946-98^{*}$ & 0.02 & 0.27 \\
\hline Ostrov Dikson ${ }^{1}$ & 20674 & $1917-98$ & $0.16^{+}$ & 0.32 \\
\hline Ostrov Rudolfa ${ }^{1}$ & 20049 & $1948-95^{*}$ & 0.10 & 0.42 \\
\hline Arkhangelsk ${ }^{2}$ & 22550 & 1883-98 & $0.34^{+++}$ & $0.61^{++}$ \\
\hline $\operatorname{Vard} \varnothing^{2}$ & 01098 & 1883-98 & $0.35^{+++}$ & $0.62^{+++}$ \\
\hline Svalbard Lufthavn ${ }^{2}$ & 01008 & 1912-98 & $0.33^{+++}$ & $0.56^{+}$ \\
\hline Bjørnøya $^{2}$ & 01028 & $1946-98^{*}$ & 0.12 & 0.43 \\
\hline Bodø $\varnothing^{2}$ & 01152 & 1883-1998 & $0.21^{++}$ & $0.53^{++}$ \\
\hline Jan Mayen $^{2}$ & 01001 & $1921-98$ & -0.04 & 0.27 \\
\hline Akureyri $^{1}$ & 04063 & 1883-1998 & $0.27^{++}$ & $0.54^{+}$ \\
\hline Angmagssalik $^{1}$ & 04360 & 1895-1998 & 0.14 & 0.43 \\
\hline Upernavik ${ }^{1}$ & 04210 & $1883-1998$ & 0.13 & 0.36 \\
\hline Barrow $^{1}$ & 70026 & 1893-1998 & 0.14 & $0.41^{+}$ \\
\hline Arctic $^{1}$ & - & 1883-1998 & $0.44^{+++}$ & $0.72^{++}$ \\
\hline
\end{tabular}

${ }^{1}$ Data source: Polyakov and others (2003b).

${ }^{2}$ Data source: CRU, Norwich.

"Time series were shortened due to data gaps.

${ }^{+}$Correlation coefficient statistically significant at the level of $p=0.1$.

${ }^{++}$Correlation coefficient statistically significant at the level of $p=0.05$.

${ }^{+++}$Correlation coefficient statistically significant at the level of $p=0.01$.

other SAT time series (e.g. Bodø or Akureyri). Based on instrumental data, Przybylak (2007) stated that for the whole Arctic the decade 1936-45 and the year 1938 were the warmest in the 20th century. Only the period 1995-2005 and the year 2005, respectively, reached and exceeded these values. This SAT pattern shows the Arctic peculiarity compared with the whole Northern Hemisphere $(\mathrm{NH})$, where the SAT maximum values at about 1940 have been exceeded since the end of the 1980s (Fig. 5; data: http:// data.giss.nasa.gov/gistemp/tabledata/NH.Ts.txt).

AN $\delta^{18} \mathrm{O}$ data show distinct similarities to the ice-core $\delta^{18} \mathrm{O}$ time series from Austfonna ice cap, Svalbard, (Isaksson and others, 2005) and Vetreniy ice cap, FJL, (Henderson, 2002) whereas the accordance to Lomonosovfonna (Isaksson and others, 2005) is not as good. AN, Austfonna (750 m a.s.l.) and Vetreniy (500 m a.s.I.) ice caps are located at relatively low altitudes and are therefore more sensitive to SAT changes. In contrast, glaciers of higher elevation like Lomonosovfonna (1250 ma.s.l.) seem to reflect primarily free atmospheric climate signals (Isaksson and others, 2005). The higher sensitivity of the lower-altitude ice caps is also visible in the broader range of $\delta^{18} \mathrm{O}$ values (about 4\% for $\mathrm{AN}$ and Austfonna for 5yrm in the 20th century) compared with Lomonosovfonna (about 2\%). The range differences may also be influenced by different impacts of sea ice and of the dampening North Atlantic, as well as by the more frequent temperature inversions at the lower altitudes as reported for Austfonna compared with Lomonosovfonna (Isaksson and others, 2005).

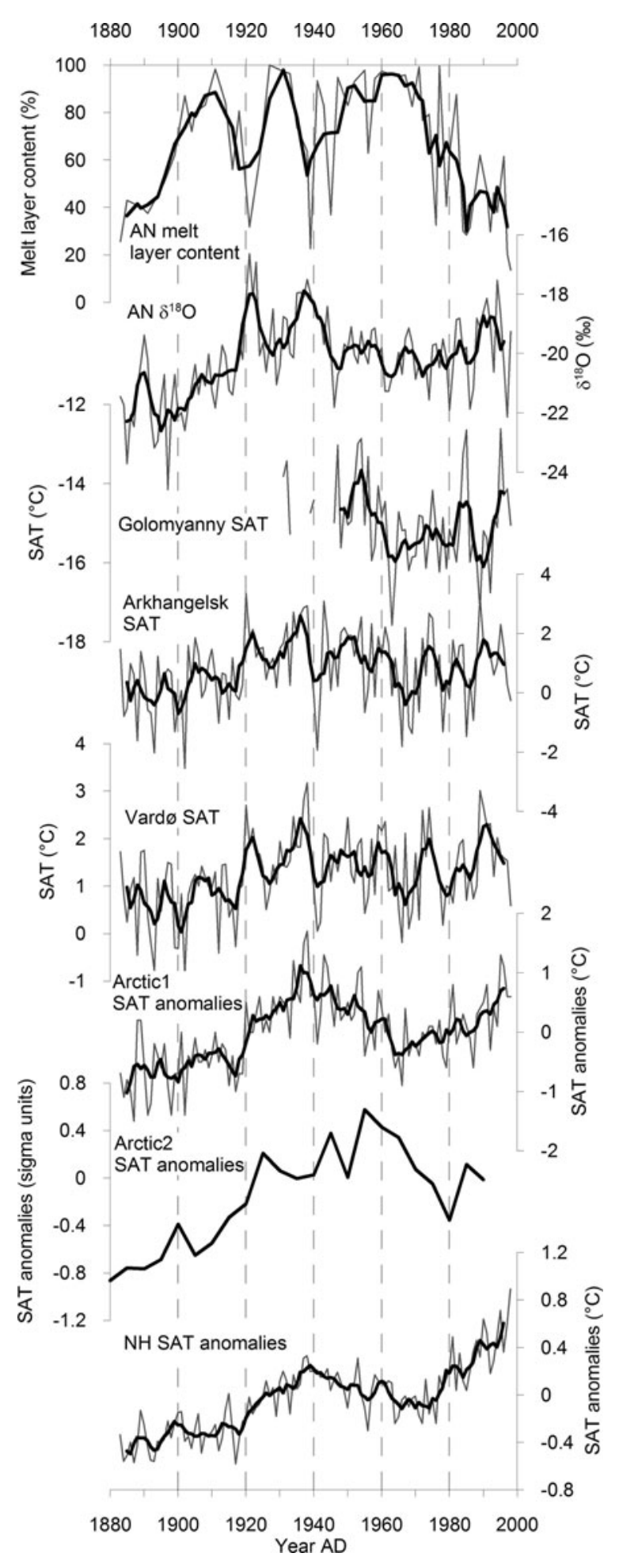

Fig. 5. Time series of the $A N$ melt-layer content, $A N \delta^{18} \mathrm{O}$, subArctic and Arctic SAT and NH SAT. The thin grey lines indicate annual mean values. The thick black lines represent $5 y$ rm values (for AN melt-layer content 1 and $3 \mathrm{~m}$ running mean values, respectively) except for Arctic2, where it represents 5 year mean values. Arctic1 displays the Arctic SAT anomalies (relative to 196190) dataset of Polyakov and others (2003b), Arctic2 the reconstructed Arctic SAT anomalies (relative to 1901-60) of Overpeck and others (1997).

In contrast to these Eurasian Arctic ice-core data, the accordance between $\mathrm{AN} \delta^{18} \mathrm{O}$ data and the often used proxy-deduced SAT time series of Overpeck and others (1997) is less pronounced (Fig. 5). This is probably caused by 
the predominance of Canadian and Alaskan Arctic proxy sites in this composite record, whereas just a few proxy records of the Eurasian Arctic are considered.

\subsection{Deuterium excess}

The second-order parameter deuterium excess $d$ (Dansgaard, 1964) in precipitation depends largely on the evaporation conditions in the moisture source region, to a lesser degree on condensation temperatures but also on secondary kinetic fractionation processes. The main controlling factors are the relative air humidity and the seasurface temperature (SST) and, to a lesser extent, wind speed during evaporation (Rozanski and others, 1993). Assuming no significant changes in the spatial distribution of the moisture source regions, variations of $d$ can be interpreted in terms of changing SST and relative humidity conditions (e.g. Hoffmann and others, 2001).

The mean $d$ values of the considered core section account for $10.7 \%$ for all single samples and $10.8 \%$ for the annual mean values, respectively (Table 1 ). These values are typical for precipitation in high-latitude coastal areas (Johnsen and others, 1989). Therefore, we assume an oceanic main moisture source, whereas substantial water recycling from the continents seems unlikely. However, the AN mean $d$ value is slightly higher than the 9.5\% for the period 1883-1990 in the Lomonosovfonna ice core (Divine and others, 2008), the only Arctic ice core outside of Greenland for which a study of $d$ was performed so far. This points to different moisture generation and transport regimes, probably due to the more remote location of SZ compared with the much more Atlantic-influenced western Svalbard.

In general, high (low) d values are caused by high (low) SST as well as by low (high) relative humidity during evaporation (Johnsen and others, 1989). However, on seasonal timescales $\mathrm{d}$ seems to be controlled mainly by the relative humidity. In the AN d record, high (low) d values in winter (summer) are connected with lower (higher) relative humidity in the moisture source region, outbalancing lower (higher) SSTs during that time. This pattern of opposite behaviour of $\delta^{18} \mathrm{O}$ and $\mathrm{d}$ corresponds with the isotopic data of the Global Network of Isotopes in Precipitation (e.g. Rozanski and others, 1993) and model calculations (Fröhlich and others, 2002).

Based on the assumption of nearly constant annual mean values of relative humidity in the moisture source region, multi-annual variations of $d$ should be related mainly to SST changes (Hoffmann and others, 2001). The AN d time series shows a distinct decreasing trend over the 115 years considered. This is a reverse picture compared with $\delta^{18} \mathrm{O}$ (Fig. 6), corresponding with the findings in the seasonal cycles of $\mathrm{d}$ and $\delta^{18} \mathrm{O}$. Only the strong $\delta^{18} \mathrm{O}$ peak about 1920 shows no counterpart in $d$ (see below). The highest $d$ values (about 12\%) occurred about 1900 and the lowest (about $9 \%$ ) in the 1990s. A similar decreasing trend is visible in the ice cores from central Greenland (Hoffmann and others, 2001), but not in the Lomonosovfonna ice core (Divine and others, 2008), where an increasing $d$ trend is visible for the period considered here.

The main feature of the AN d time series is the strong decrease since 1970, also detectable in the ice-core records from central Greenland (Hoffmann and others, 2001), but not in the Lomonosovfonna ice core, which shows an increase (Divine and others, 2008). Assuming the positive

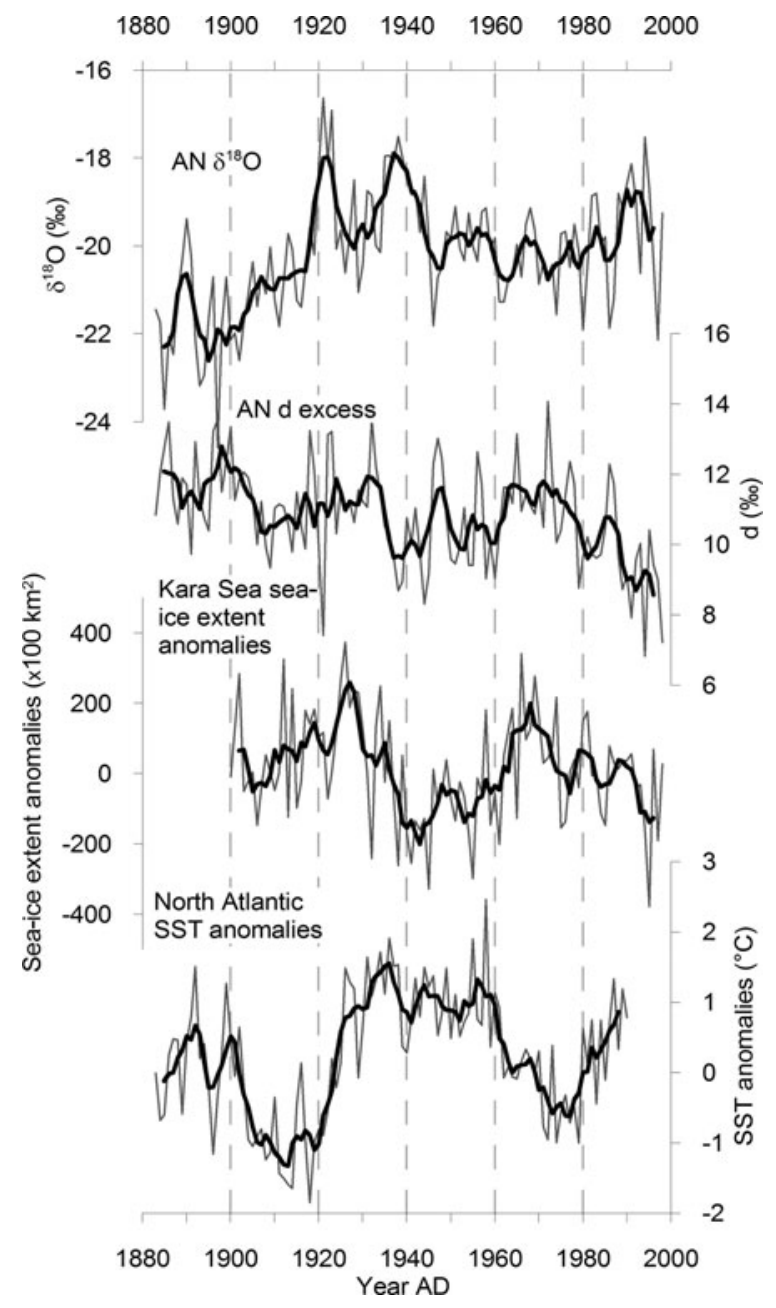

Fig. 6. Time series of $A N \delta^{18} \mathrm{O}, \mathrm{AN} d$, Kara Sea August sea-ice anomalies (Polyakov and others, 2003a, computed against mean of the entire period) and North Atlantic SST anomalies (Gray and others, 2004). The thin grey lines indicate annual mean values; the thick black lines show $5 y$ rm.

d-SST relationship both the general decreasing trend and the strong d decrease after 1970 in the AN d record would indicate corresponding SST decreases in the main moisture source region. However, no comparable cooling trends are visible in the SST time series of the North Atlantic $\left(0-70^{\circ} \mathrm{N}\right)$ (Gray and others, 2004; data: ftp://ftp.ncdc.noaa.gov/pub/ data/paleo/treering/reconstructions/amo-gray2004.txt), which is the supposed main moisture source for precipitation reaching AN ice cap (Fig. 6), as well as in the NH SAT record (Fig. 5). Opposed to the AN d record, the North Atlantic SST has increased strongly since 1970. Such an opposite behaviour is also detectable about 1940, where a distinct $d$ minimum was accompanied by high SST values. This pattern indicates that in hemispherical warmer periods (e.g. about 1940 and since 1970; Fig. 5) AN ice cap receives more precipitation from moisture evaporated at lower SSTs, for example due to a northward shift of the moisture source or a significant moisture contribution of a secondary regional source (Johnsen and others, 1989). Since most precipitation on SZ is caused by air masses moving from the south and southwest, the Kara Sea could be a regional moisture source (Fig. 1) with its sea-ice cover as the main controlling factor for summer and autumn evaporation. The time series of Kara Sea August sea-ice extent anomalies 
(Polyakov and others, 2003a; data: http://www.frontier. iarc.uaf.edu/ igor/research/ice/icedata.php) shows a pattern similar to AN d data $\left(r_{5 y \mathrm{rm}}=0.51\right.$ for detrended data, $p=0.05$; Fig. 6). A low sea-ice extent in the Kara Sea allows higher evaporation rates and leads to higher contribution of regional moisture to $\mathrm{AN}$ ice-cap precipitation. This results in lower $d$ values due to the lower SST of the Kara Sea compared with the North Atlantic. In contrast, high sea-ice extent prevents a considerable regional moisture contribution, preserving the initially higher $d$ values. The missing $d$ counterpart of the $1920 \delta^{18} \mathrm{O}$ peak can also be explained with this approach. The first part of the strong early 20thcentury warming about 1920 occurred primarily in the winter season (Polyakov and others, 2003b). This did not lead to a substantial decrease in sea-ice extent in the Kara Sea and therefore not to a considerable regional moisture contribution and a decrease of $d$ values. Since 1930 a warming of the non-winter season is perceptible, causing the absolute SAT maximum about 1938 (Polyakov and others, 2003b). This resulted in a corresponding decrease of sea-ice extent, leading to an amplified regional evaporation and, thus, a minimum in $\mathrm{d}$.

Therefore, we assume the Kara Sea to be an important secondary moisture source region for the air masses reaching SZ, as well as the AN deuterium excess to be an indicator of temperature changes in the surrounding seas and the connected sea-ice extent changes. However, this is not the case for the $d$ record of the Lomonosovfonna ice core, which can be interpreted as a proxy for the SST variability of the mid-latitude western North Atlantic (Divine and others, 2008).

\subsection{Melt-layer content}

The amount of melt layers in ice cores is a proxy for the summer warmth at the ice-cap surface (Koerner, 1977). We calculated the melt-layer content by the proportion of meltlayer ice per metre by weight. As melt layer we considered ice, which consists of firn, infiltrated by a visible content of meltwater, independent of the amount of meltwater. Summertime meltwater infiltration on AN ice cap is irregular, as shown by Fritzsche and others (2005). Percolation deeper than the corresponding annual layer leading to the formation of superimposed melt features may occur, at least in the warmest summers (section 3.2). Consequently, as a nearly annual resolution is not possible, we identified the meltlayer content per metre.

The melt-layer content in the AN ice core shows a strong increase at about the beginning of the 20th century, remains on a high level until about 1970, despite distinct variations, and exhibits a strong decrease in the most recent decades (Fig. 5). The ice cores from Vetreniy ice cap (Henderson, 2002) and Austfonna ice cap (Watanabe and other, 2001) show similar melt-layer records, in contrast to the Lomonosovfonna melt-layer time series (Kekonen and others, 2005).

Whereas the first increase in the AN melt-layer record is also perceptible in a rise in the $\delta^{18} \mathrm{O}$ time series, there are distinct differences between both proxies later on. Around the $\delta^{18} \mathrm{O}$-derived SAT maxima at about 1920 and 1940, as well as in the last decades, the melt-layer content shows sharp declines, whereas it exhibits higher values in the cooler 1950s and 1960s, indicating different seasonal temperature trends. For example, the strong warmings at about 1920 and 1940 occurred primarily in winter and autumn, which is supported by the studies of Polyakov and others (2003b; see above) and of Henderson (2002) for the Vetreniy ice core. We did not find any correspondence between the melt-layer content and the Golomyanny summer SAT record (not shown here), which is influenced mainly by the cold Kara Sea due to melting sea ice. However, we assume that the melt-layer content in the $\mathrm{AN}$ ice core reflects predominantly the local summer conditions at the ice-cap surface, determined not only by the temperature, but also by the energy balance. Hence the significance of the melt-layer content in terms of regional SAT conditions is limited, at least on such short timescales as considered here.

\subsection{Major ions}

The ion record of ice cores reflects the atmospheric aerosol concentrations (e.g. Legrand and Mayewski, 1997). However, ions deposited in glaciers with percolation are subject to post-depositional changes (Koerner, 1997). The initially deposited AN chemical profile is superimposed by melting, infiltration and refreezing processes. Weiler and others (2005) found that the AN ion record does not reflect seasonal atmospheric changes, but can be considered as an annually varying melting/refreezing signal. Most years seem to be represented by a peak of the more conservative ions such as sodium, which was used to achieve a depth-age scale (Weiler and others, 2005; see also section 5). However, using mean values (here: $5 y$ rm values) seems to be promising to detect lower-resolution changes in ice-core chemistry. In this subsection, we focus on 20th-century trends in AN ion data and two singular events, which are assumed to be of volcanic origin (see below).

The sea-salt ions sodium and chloride increased from a relatively low level at about 1900 to maximum values between 1910 and 1925 (Fig. 7). From this time the sea-salt ions show a decreasing trend. In the most recent years, values comparable to those at about 1900 were reached. Nevertheless, until about 1970 they remained on a high level characterized by a high-frequency variability. The period $1900-70$ is characterized by the highest melt-layer content in the core section shown here. Therefore, the high variability could be caused or strengthened by meltwater percolation due to accumulation of leached ions in or above a melt layer. This assumption is supported by similar variations of the other ions of sea-salt origin: magnesium, calcium and (not shown here) potassium.

Similar records of sea-salt ions with a mid-20th-century maximum and a distinct decrease thereafter are also found in the Vetreniy ice core (Henderson, 2002), in the Austfonna ice core (Watanabe and others, 2001) with maximum values for 1920-63 and, less pronounced, in the Lomonosovfonna ice core (Isaksson and others, 2001; Kekonen and others, 2005). Kekonen and others (2005) attributed this decrease to a substantial loss of ions due to increased melting and runoff, whereas Isaksson and others (2001) stated a decreasing deposition.

The magnesium to sodium ratio, introduced as a sensitive indicator for meltwater percolation in the Austfonna ice core by lizuka and others (2002), shows no long-lasting decrease (Fig. 7). Only three short-term drops about 1920, 1930 and 1950 are detectable, accompanied by increased values in the years before. This indicates short phases of preferential elution of magnesium with respect to sodium and accumulation in deeper layers. However, no decline of this ratio in the last few decades is perceptible, corresponding to the decrease in sea-salt ion concentration. 
Additionally, the melt-layer content shows the lowest values of the 20th century for this period, indicating that an increased loss of ions owing to increased melting and runoff seems unlikely. Hence the decreasing sea-salt ion trend favours a decreasing deposition due to lower wind speed, a change of dominating air masses or storm tracks. Since the Svalbard and FJL ice cores show similar patterns, the reasons for this decrease seem not to be only regional, but on a larger scale, covering at least parts of the Eurasian Arctic. However, a possible further growth of AN ice cap with a subsequent rise in altitude due to higher values of mean annual layer thickness since 1935 (see section 5) could also have contributed.

Short-term peaks in ice-core ion time series are often caused by major volcanic eruptions. During these eruptions large amounts of aerosols are injected into the atmosphere, leading to increased ion concentrations, particularly of sulphate (e.g. Legrand and Mayewski, 1997). In the AN sulphate record, two outstanding sharp peaks are visible, ascribed to the years 1956 and 1912 by $\delta^{18}$ O cycle counting (Fig. 7). These values represent the highest values of sulphate concentrations for at least the last 1500 years, and of electrical conductivity in the whole AN ice core. The peaks were interpreted as imprints of the large volcanic eruptions of Bezymianny in 1956 and Katmai in 1912 and were therefore used as reference horizons for our age model. It is notable that for both events not only sulphate increased significantly, but all ions show enlarged values (Fig. 7). In both cases the magnesium to sodium ratio shows smaller declines in the layers directly above the peaks (Fig. 7), indicating leaching of ions. Therefore, it is likely that these peaks were amplified by infiltration processes and accumulation of ions. However, the peak linked to the Bezymianny eruption was identified clearly as of volcanic origin by Weiler and others (2005), whereas this was not necessarily the case for the 1912 peak. The Bezymianny eruption was also detected in the Lomonosovfonna ice-core sulphate record, whereas there was no hint for the Katmai-related peak (Isaksson and others, 2001; Kekonen and others, 2005). However, there are spikes in the Austfonna sulphate profile (fig. 6 in lizuka and others, 2002) which could be related to the two peaks in the AN ice core. Also, in the ice core from Vetreniy ice cap, a strong peak in sulphate is perceptible about 1956 (Henderson 2002), even though not attributed to the Bezymianny eruption.

The concentrations of nitrate and sulphate in the AN ice core show a distinct anthropogenic imprint with a strong increase in the 1960s, maximum values about 1970 and decreasing values thereafter. This pattern corresponds to the records of the Svalbard and FJL ice cores (Isaksson and others, 2001; Watanabe and others, 2001; Henderson, 2002; Kekonen and others, 2005) and was attributed to regional industrial sources by Weiler and others (2005), who discussed these records in detail, even though with the slightly different age model mentioned above.

\section{CONCLUSIONS}

This study deals with the uppermost $57 \mathrm{~m}$ of the recently drilled ice core of $\mathrm{AN}$ ice cap, covering the time period 1883-1998. To evaluate the palaeoclimatic significance of the ice-core data, we compared them to meteorological and other proxy data. We show that the AN ice core reflects Eurasian Arctic climate and environmental changes,

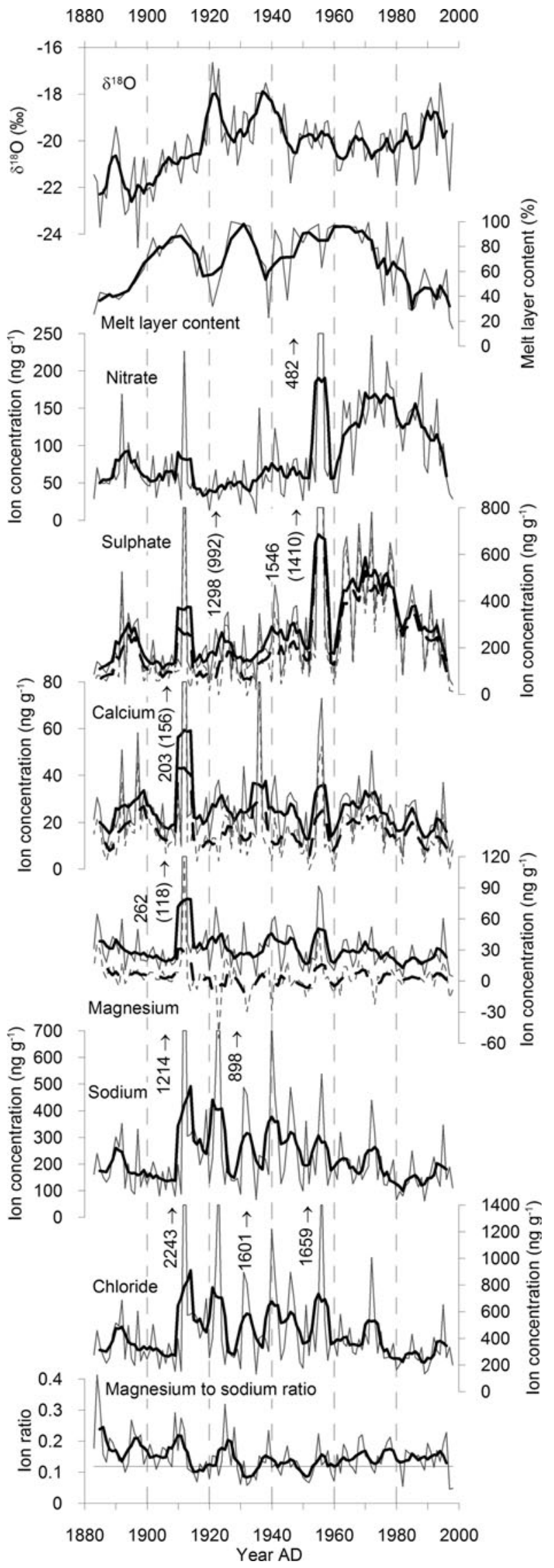

Fig. 7. Time series of $\mathrm{AN} \delta^{18} \mathrm{O}, \mathrm{AN}$ melt-layer content, $\mathrm{AN}$ major ions and magnesium to sodium ratio by weight. The thin grey lines indicate annual mean values; the thick black lines indicate $5 \mathrm{yrm}$ (for AN melt-layer content 1 and $3 \mathrm{~m}$ running mean values, respectively). The dashed lines as well as numbers in parentheses represent non-sea-salt values. The horizontal black line indicates the magnesium to sodium ratio of sea water. 
although the ice cap is affected by summertime melting and infiltration processes. The main conclusions are:

1. Despite overprinting by summertime melting and infiltration processes, seasonal stable water-isotope cycles can be recognized over most of the section of the AN ice core considered here. In combination with the use of reference horizons, they enable a high-resolution dating of the AN ice core.

2. The multi-annual $\mathrm{AN} \delta^{18} \mathrm{O}$ time series shows strong similarities and correlations to instrumental SAT data from a couple of meteorological stations from the subArctic and Arctic. Hence AN $\delta^{18} \mathrm{O}$ data are a valuable proxy for mean Eurasian Arctic SAT, providing unique information for this poorly investigated region, particularly beyond the instrumental records.

3. In the warmest periods of this record, low $d$ values connected with minima in the Kara Sea sea-ice extent indicate an increasing role of the Kara Sea as an important regional moisture source for the precipitation feeding AN ice cap.

4. The melt-layer content has no large-scale significance as proxy for SAT, since it reflects predominantly summer conditions at the ice-cap surface.

5. The AN ion record is more affected by meltwater percolation than the stable-isotope record. Nevertheless, long-term trends in atmospheric aerosol content as well as short-term events like the volcanic eruptions of Bezymianny in 1956 and Katmai in 1912 can be deduced.

\section{ACKNOWLEDGEMENTS}

We thank all the people who, in various ways, have contributed to the Severnaya Zemlya ice-core project. This study was funded by the state of Berlin (NaFöG PhD scholarship). The drilling project was funded by the German Ministry of Education and Research (03PL027A). We thank E. Isaksson and an anonymous reviewer for helpful comments which improved the quality of the manuscript.

\section{REFERENCES}

Alexandrov, E.I., V.F. Radinov and P.N. Svyashchennikov. 2000. Climatic regime and its changes in the region of the Barents and Kara seas. In Transport and fate of contaminants in the northern seas. Sea ice project package. St Petersburg, Arctic and Antarctic Research Institute. (AARI final report.)

Bolshiyanov, D.Y. and V.M. Makeyev. 1995. Arkhipelag Severnaya Zemlya: oledeneniye, istoriya razvitiya prirodnoy sredy (Severnaya Zemlya Archipelago: glaciation and historical development of the natural environment). St Petersburg, Gidrometeoizdat.

Brohan, P., J.J. Kennedy, I. Harris, S.F.B. Tett and P. D. Jones. 2006. Uncertainty estimates in regional and global observed temperature changes: a new data set from 1850. J. Geophys. Res., 111(12), D12106. (10.1029/2005JD006548.)

Craig, H. 1961. Isotopic variations in meteoric waters. Science, 133(3465), 1702-1703.

Dansgaard, W. 1964. Stable isotopes in precipitation. Tellus, 16(4), 436-468.
Divine, D.V. and 8 others. 2008. Deuterium excess record from a small Arctic ice cap. J. Geophys. Res., 113(D19), D19104. (10.1029/2008JD010076.)

Dowdeswell, J.A. and 10 others. 2002. Form and flow of the Academy of Sciences ice cap, Severnaya Zemlya, Russian High Arctic. J. Geophys. Res., 107(B4), 2076. (10.1029/ 2000JB000129.)

Fritzsche, D. and 6 others. 2002. A new deep ice core from Akademii Nauk ice cap, Severnaya Zemlya, Eurasian Arctic: first results. Ann. Glaciol., 35, 25-28.

Fritzsche, D. and 6 others. 2005. A 275 year ice-core record from Akademii Nauk ice cap, Severnaya Zemlya, Russian Arctic. Ann. Glaciol., 42, 361-366.

Fröhlich, K., J.J. Gibson, and P.K. Aggarwal. 2002. Deuterium excess in precipitation and its climatological significance. Study of environmental change using isotope techniques. Vienna International Atomic Energy Agency, 54-65. (C\&S Papers Series 13/P.)

Gray, S.T., L.J. Graumlich, J.L. Betancourt and G.T. Pederson. 2004. A tree-ring based reconstruction of the Atlantic Multidecadal Oscillation since 1567 A.D. Geophys. Res. Lett., 31(12), L12205. (10.1029/2004GL019932.)

Henderson, K.A. 2002. An ice core paleoclimate study of Windy Dome, Franz Josef Land (Russia): development of a recent climate history for the Barents Sea. (PhD thesis, The Ohio State University.)

Hoffmann, G., J. Jouzel and S. Johnsen. 2001. Deuterium excess record from central Greenland over the last millennium: hints of a North Atlantic signal during the Little Ice Age. J. Geophys. Res., 106(D13), 14,265-14,274.

lizuka, Y., M. Igarashi, K. Kamiyama, H. Motoyama and O. Watanabe. 2002. Ratios of $\mathrm{Mg}^{2+} / \mathrm{Na}^{+}$in snowpack and an ice core at Austfonna ice cap, Svalbard, as an indicator of seasonal melting. J. Glaciol., 48(162), 452-460.

Isaksson, E. and 14 others. 2001. A new ice-core record from Lomonosovfonna, Svalbard: viewing the 1920-97 data in relation to present climate and environmental conditions. J. Glaciol., 47(157), 335-345.

Isaksson, E. and 10 others. 2005. Two ice-core ${ }^{18} \mathrm{O}$ records from Svalbard illustrating climate and sea-ice variability over the last 400 years. Holocene, 15(4), 501-509.

Johnsen, S.J., W. Dansgaard and J.W.C. White. 1989. The origin of Arctic precipitation under present and glacial conditions. Tellus, 41B $(4)$, 452-468.

Kekonen, T. and 6 others. 2005. The 800 year long ion record from the Lomonosovfonna (Svalbard) ice core. J. Geophys. Res., 110(D7), D07304. (10.1029/2004JD005223.)

Koerner, R.M. 1977. Devon Island ice cap: core stratigraphy and paleoclimate. Science, 196(4285), 15-18.

Koerner, R.M. 1997. Some comments on climatic reconstructions from ice cores drilled in areas of high melt. J. Glaciol., 43(143), 90-97.

Koerner, R.M. and D.A. Fisher. 2002. Ice-core evidence for widespread Arctic glacier retreat in the Last Interglacial and the early Holocene. Ann. Glaciol., 35, 19-24.

Kotlyakov, V.M., S.M. Arkhipov, K.A. Henderson and O.V. Nagornov. 2004. Deep drilling of glaciers in Eurasian Arctic as a source of paleoclimate records. Quat. Sci. Rev., 23(11-13), 1371-1390.

Kuhn, M. 2000. Severnaja automatic weather station data (Severnaja Zemlja). In The response of Arctic ice mass to climate change (ICEMASS). Third Year Report (JanuaryDecember 2000). European Commission, Framework IV, Environment and Climate Research Programme (DG XII), contract ENV4-CT97-0490. Oslo, University of Oslo, 7-8-7-14.

Legrand, M. and P. Mayewski. 1997. Glaciochemistry of polar ice cores: a review. Rev. Geophys., 35(3), 219-243.

Meyer, H., L. Schönicke, U. Wand, H.W. Hubberten and H. Friedrichsen. 2000. Isotope studies of hydrogen and oxygen in ground ice. Isot. Environ. Health Stud., 36(2), 133-149. 
North Greenland Ice Core Project (NorthGRIP) Members. 2004. High-resolution record of Northern Hemisphere climate extending into the last interglacial period. Nature, 431(7005), 147-151.

Overpeck, J. and 17 others. 1997. Arctic environmental change of the last four centuries. Science, 278(5341), 1251-1256.

Pinglot, J.F. and 13 others. 2003. Ice cores from Arctic subpolar glaciers: chronology and post-depositional processes deduced from radioactivity measurements. J. Glaciol., 49(164), 149-158.

Pohjola, V. and 7 others. 2002a. Effect of periodic melting on geochemical and isotopic signals in an ice core on Lomonosovfonna, Svalbard. J. Geophys. Res., 107(D4), 4036. (10.1029/ 2000JD000149.)

Pohjola, V.A. and 6 others. 2002b. Reconstruction of three centuries of annual accumulation rates based on the record of stable isotopes of water from Lomonosovfonna, Svalbard. Ann. Glaciol., 35, 57-62.

Polyakov, I.V. and 8 others. 2003a. Long-term ice variability in Arctic marginal seas. J. Climate, 16(12), 2078-2085.

Polyakov, I.V. and 7 others. 2003b. Variability and trends of air temperature and pressure in the maritime Arctic. J. Climate, 16(12), 2067-2077.

Przybylak, R. 2007. Recent air-temperature changes in the Arctic. Ann. Glaciol., 46, 316-324.

Rozanski, K., L. Araguás-Araguás and R. Gonfiantini. 1993. Isotopic patterns in modern global precipitation. In Swart, P.K., K.C. Lohmann, J.A. McKenzie and S. Savin, eds. Climate change in continental isotopic records. Washington, DC, American Geophysical Union, 1-36.
Ruth, U. and 6 others. 2004. Comprehensive 1000 year climatic history from an intermediate-depth ice core from the south dome of Berkner Island, Antarctica: methods, dating and first results. Ann. Glaciol., 39, 146-154.

Svensson, A. and 7 others. 2005. Visual stratigraphy of the North Greenland Ice Core Project (NorthGRIP) ice core during the last glacial period. J. Geophys. Res., 110(D2), D02108. (10.1029/ 2004JD005134.)

Tarussov, A. 1992. The Arctic from Svalbard to Severnaya Zemlya: climatic reconstructions from ice cores. In Bradley, R.S. and P.D. Jones, eds. Climate since A.D. 1500. London and New York, Routledge, 505-516.

Vinogradova, A.A. and V.A. Egorov. 1996. Long-range pollutant transport into the Russian Arctic. Atmos. Ocean Phys., 32(6), 731-737.

Vinogradova, A.A. and T.Ya. Ponomareva. 1999. Air exchange between the Russian Arctic and the surrounding atmosphere in spring-summer periods from 1986 to 1995. Atmos. Ocean Phys., 35(5), 532-539.

Watanabe, O. and 7 others. 2001. Studies on climatic and environmental changes during the last few hundred years using ice cores from various sites in Nordaustlandet, Svalbard. Mem. Natl. Inst. Polar Res., Special Issue 54, 227-242.

Weiler, K., H. Fischer, D. Fritzsche, U. Ruth, F. Wilhelms and H. Miller. 2005. Glaciochemical reconnaissance of a new ice core from Severnaya Zemlya, Eurasian Arctic. J. Glaciol., 51(172), 64-74.

Wilhelms, F. 2000. Messung dielektrischer Eigenschaften polarer Eiskerne. Ber. Polarforsch./Rep. Pol. Res. 367.

MS received 18 May 2008 and accepted in revised form 1 September 2008 